\title{
Myocardial infarction in male and female dominated occupations
}

\author{
Piroska Östlin, Lars Alfredsson, Niklas Hammar, Christina Reuterwall
}

National Public Health

Commission, and

Department of

Occupational Health,

Karolinska Hospital,

Stockholm, Sweden

P Östlin

Division of

Epidemiology,

Department of

Environmental

Medicine, Karolinska

Institute, Stockholm,

Sweden

L Alfredsson

N Hammar

Division of

Epidemiology,

Stockholm County

Council, Stockholm,

Sweden

N Hammar

C Reuterwall

\section{Department of}

Occupational Health, National Institute for

Working Life,

Stockholm, Sweden

C Reuterwall

Correspondence to:

Dr Piroska Östlin, National

Public Health Commission,

S-103 33 Stockholm,

Sweden. Email piroska.ostlin

(a)social.ministry.se

Accepted 24 March 1998

\begin{abstract}
The aim of the study was to investigate whether workers in jobs dominated by the opposite sex have an increased risk of myocardial infarction (MI). A casereferent study was carried out to estimate the relative risk of first $M I$ in different occupational groups. The study base comprised all men and women in five counties in the middle of Sweden during 1976-84. Cases of MI were identified from both hospital discharge records and death records. Information on occupation was obtained from two consecutive censuses. Primary health related selection was analysed for men with data from the physical examination of conscripts to compulsory military service in 1969-70 combined with data from the censuses of 1970-90 and data on early retirement in 1971-92. Increased risk of MI was found among both women (relative risk (RR) $1.41,95 \%$ confidence interval (95\% CI) 1.15 to 1.73$)$ and men $(1.21,1.10$ to 1.32$)$ in blue collar jobs where men predominate, and among men with white collar jobs $(1.26,1.09$ to 1.45$)$ where women predominate. However, the increased risk among men in white collar jobs was probably due to negative health selection into these occupations. These results do not support the notion that being of the sexual minority in an occupation is in itself an important risk factor for MI.

(Occup Environ Med 1998;55:642-644)
\end{abstract}

Keywords: male dominated; female dominated; myocardial infarction

The risk for myocardial infarction (MI) differs considerably between people with different occupations, ${ }^{1}$ and it has been suggested that people of the sexual minority in a workplace are under particular stress in their working life. ${ }^{2}$

The aim of this study was to examine whether women working in occupational groups where men predominate, and men working in groups where women predominate, run a greater risk of $\mathrm{MI}$ than do other gainfully employed women and men, respectively. To elucidate whether such an increased risk could be due to being in the minority in itself, we also analysed the risk of MI among men with jobs where men predominate and women with jobs where women predominate.

\section{Methods}

The study base comprised the population aged 30-74 who resided in five Swedish counties, including Stockholm, between 1976 and 1984 . The relation between occupation and MI was examined with a case-referent study base. Incident cases of MI in the study base were identified by combining information from the national register on causes of deaths with information from inpatient hospital records for the five counties. From the inpatient records, all admissions to hospital with a discharge diagnosis of MI (Swedish version of ICD-8 code 410.00 or 410.99 ) were compiled. From the cause of death register all deaths due to MI within the study base were identified. In all, 46 840 cases of MI were identified within the study base (34 604 men and 12236 women). For each case, two referents were selected from the study base through random sampling, stratified by sex, age (5-year age groups), and year of infarction of the cases. Referents were selected from registers listing the population of the five counties at the end of each year in 1976-84. In all, 93680 referents were selected in this way (69 208 men and 24472 women).

Information about occupation for cases and referents was obtained from the 1970 and 1975 censuses by record linkage, with the Swedish personal identification numbers.

We estimated the relative risk of MI for women with men's jobs compared with other gainfully employed women, and for men with women's jobs compared with other gainfully employed men. Blue collar and white collar workers were analysed separately.

Stratification criteria included age, county of residence, and calendar year. Relative risks (RRs) were approximated by odds ratios according to the Mantel-Haenszel method and $95 \%$ confidence intervals ( $95 \%$ CIs) were calculated according to the methods proposed by Robins et al. ${ }^{3}$ Also, the absolute differences in risk were calculated separately for men and women with different occupations, based on estimates of incidence. 
Table 1 Relative risks* (RRs) of myocardial infarction for women and men (aged 30-64) in male and female dominated occupations where the relevant sex make up $>80 \%$ of the workforce (reference group in each case is other women or other men)

\begin{tabular}{|c|c|c|}
\hline & Men's jobs & Women's jobs \\
\hline \multicolumn{3}{|l|}{ Women: } \\
\hline \multicolumn{3}{|l|}{ All jobs: $†$} \\
\hline RR & 1.32 & 0.98 \\
\hline $95 \% \mathrm{CI}$ & 1.13 to 1.54 & 0.88 to 1.09 \\
\hline $\mathrm{n}$ & 273 & 1372 \\
\hline \multicolumn{3}{|c|}{ Blue collar jobs: } \\
\hline $\mathrm{RR}$ & 1.41 & 0.92 \\
\hline $95 \% \mathrm{CI}$ & 1.15 to 1.73 & 0.79 to 1.07 \\
\hline $\mathrm{n}$ & 180 & 951 \\
\hline \multicolumn{3}{|c|}{ White collar jobs: } \\
\hline RR & 1.11 & 0.95 \\
\hline $95 \% \mathrm{CI}$ & 0.83 to 1.47 & 0.80 to 1.11 \\
\hline $\mathrm{n}$ & 72 & 417 \\
\hline \multicolumn{3}{|l|}{ Men: } \\
\hline \multicolumn{3}{|l|}{ All jobs: $\dagger$} \\
\hline $\mathrm{RR}$ & 1.08 & 1.07 \\
\hline $95 \% \mathrm{CI}$ & 1.02 to 1.14 & 0.97 to 1.18 \\
\hline $\mathrm{n}$ & 8739 & 594 \\
\hline \multicolumn{3}{|c|}{ Blue collar jobs: } \\
\hline $\mathrm{RR}$ & 1.21 & 0.91 \\
\hline $95 \% \mathrm{CI}$ & 1.10 to 1.32 & 0.79 to 1.04 \\
\hline $\mathrm{n}$ & 4591 & 288 \\
\hline \multicolumn{3}{|c|}{ White collar jobs: } \\
\hline $\mathrm{RR}$ & 0.99 & 1.26 \\
\hline $95 \% \mathrm{CI}$ & 0.92 to 1.06 & 1.09 to 1.45 \\
\hline $\mathrm{n}$ & 3332 & 290 \\
\hline
\end{tabular}

*Adjusted for age, county of residence, and calendar year. †Includes blue and white collar workers and self employed people.

\section{Results}

In total, women with men's jobs had a $32 \%$ greater risk of MI than women with other gainful employment (table). This increased risk was found primarily among women with blue collar jobs. These had a $41 \%$ greater risk. There was, however, no substantially increased risk among women with men's white collar jobs. Corresponding risk analysis for men with men's jobs showed a similar pattern: there was a $21 \%$ increased risk for men with blue collar jobs and no increased risk for men with white collar jobs. On comparison of age standardised incidence, the increased risk for female blue collar workers corresponds in absolute numbers to five extra cases per 10000 person-years (incidence $=0.0014$ cases $/$ person-year). The increased risk for male blue collar workers corresponds in absolute numbers to an age standardised difference of 15 cases/10 000 personyears (incidence $=0.015$ cases $/$ person-year).

Among men with women's jobs, all categories, we found no substantially increased risk of MI compared with other gainfully employed men. Nor was there any increased risk among the men with blue collar women's jobs. On the other hand, male white collar workers with women's jobs seemed to be at greater risk of MI than were other male white collar workers $(R R$ 1.26). No such increased risks were found among female blue and white collar workers with corresponding jobs.

Among men with white collar women's jobs, nearly all worked as secretaries. Of the 290 cases among the men aged 30 to 64 in this group, 277 were employed in secretarial positions, primarily in the public service sector and in insurance.

We were able to use information from the study on military conscripts to examine the health status at enlistment of the young men who were employed as secretaries 10 years later. The relative risk of being forced into early retirement from a secretarial position within 20 years of enlistment was also calculated. At enlistment, men who later became secretaries reported more often than men who later held other types of white collar jobs, that they often had headaches, were often nervous, had taken medication for nervous complaints, and often felt insecure in company. The men who later became secretaries had lower scores in the working capacity and in the hand grip test, suggesting subaverage physical strength. Among male secretaries we also noted an increased risk of early retirement both for all causes (RR 2.55, 95\% CI 1.44 to 4.53) and specifically for psychiatric reasons (RR 2.35, 95\% CI 1.48-3.74).

\section{Discussion}

The study was based on information from register records and the results could have been affected by misclassification of exposure or of disease. Because the information on occupation was gathered before the observation period, it is safe to assume that any misclassification of occupation is unrelated to the onset of cardiac disease. There is no reason to suspect that the disease had been classified as dependent of exposure in this study. The studied exposure (to be a woman in a man's job or to be a man in a woman's job) is not likely to selectively influence a diagnosis such as MI. On the whole, in this study, misclassification of disease would thus mainly weaken statistical associations. Thus, the observed increased risks for blue collar women workers with men's jobs and for male white collar workers with women's jobs are unlikely to be due to errors of disease misclassification. On the other hand, misclassification of exposure or of disease may have led to a failure to identify increased risks in other occupational groups.

An increased risk of MI within certain occupational groups could, in principle, be due to disproportionate recruitment to these jobs on the basis of health. For women who choose physically demanding blue collar jobs this explanation is unlikely. For men who choose women's white collar jobs, on the other hand, this negative health related selection may well explain the increased risk of MI. ${ }^{4}$ Other Swedish studies of, for example, sick leave, confirm that male secretaries have an increased risk of illness. ${ }^{5}$

It is not possible, on the basis of this study, to determine the cause of the increased risk of MI among workers with male dominated blue collar jobs. The increased risk, among both women and men, might be due to conditions in the work environment or lifestyle factors related to these occupations. That women with men's blue collar jobs are at increased risk of MI may be partly related to high demands of the work in combination with low decision latitude. ${ }^{67}$

The increased risk of MI among women with male dominated blue collar jobs can probably not be explained on the basis of the women's minority status alone, as men with the same 
jobs run at least the same risk, measured in absolute terms. Rather, the results suggest that the risk factors of $\mathrm{MI}$, inherent in those blue collar jobs in which men make up most of the workforce, influence workers of both sexes. However, we cannot exclude that women's minority status in men's blue collar jobs contributes to their increased risk of MI. There is an urgent need to identify and take measures against the risk factors that affect both women and men with these jobs.

This study was supported by grants from the Swedish Council for Social Research.

1 Ahlbom A. Work environment and myocardial infarction In: B Järvholm, ed. Working life and health: a Swedish survey. Stockholm: National Board of Occupational Safety and
Health, National Institute for Working Life, Swedish Council for Work Life Research, 1996.

2 Hunt K, Emslie C. Men's work, women's work. Is there an effect of taking account of occupational sex ratios on gender differences in health? In: K Orth-Gomer, $M$ Chesney, Wenger N, eds. Stress and heart disease. Hillsdale, NJ: Lawrence Erlbaum, 1997.

3 Robins J, Greenland S, Breslow NE, A general estimator for the variance of the Mantel-Haenszel odds ratio. Am $\mathcal{F} E \mathrm{pi}$ demiol 1986;124:719-23.

4 Östlin P. Negative health selection into physically light occupations. F Epidemiol Community Health 1988;42:1526.

5 Alexanderson K, Leijon M, Åkerlind I, et al. Epidemiology of sickness absence in a Swedish County in 1985, 1986, and 1987. Scand F Soc Med 1994;22:27-34.

6 Hall E. Gender, work control and stress: a theoretical discussion and an empirical test. Int $\mathcal{F}$ Health Services 1989; discussion

7 Östlin P. Work and gender. In: B Järvholm, ed. Working life and health: a Swedish survey. Stockholm: National Board of Occupational Safety and Health, National Institute for Working Life, Swedish Council for Work Life Research, 1996:67-71

\section{Vancouver style}

All manuscripts submitted to Occup Environ Med should conform to the uniform requirements for manuscripts submitted to biomedical journals (known as the Vancouver style.)

Occup Environ Med, together with many other international biomedical journals, has agreed to accept articles prepared in accordance with the Vancouver style. The style (described in full in the $\mathcal{F} A M A[1]$ ) is intended to standardise requirements for authors, and is the same as in this issue.

References should be numbered consecutively in the order in which they are first mentioned in the text by Arabic numerals on the line in square brackets on each occasion the reference is cited (Manson[1] confirmed other reports[2][3][4][5]). In future references to papers submitted to Occup Environ Med should include: the names of all authors if there are three or less or, if there are more, the first three followed by et al; the title of journal articles or book chapters; the titles of journals abbreviated according to the style of Index Medicus; and the first and final page numbers of the article or chapter. Titles not in Index Medicus should be given in full.

Examples of common forms of references are:

1 International Committee of Medical Journal Editors. Uniform requirements for manuscripts submitted to biomed journals. FAMA 1993;269:2282-6.

2 Soter NA, Wasserman SI, Austen KF. Cold urticaria release into the circulation of histmaine and eosinophil chemotactic factor of anaphylaxis during cold challenge. N Engl f Med 1976;294:687-90.

3 Weinstein L, Swartz MN. Pathogenic properties of invading micro-organisms. In: Sodeman WA Jr, Sodeman WA eds. Pathologic physiology, mechanisms of disease. Philadelphia: W B Saunders, 1974:457-72. 